\title{
PEMASARAN DAN KEUNGGULAN BERSAING (Studi Perusahaan Finance di Wonogiri)
}

\section{MARKETING AND COMPETITIVE ADVANTAGES (Study of Finance Companies in Wonogiri)}

\author{
Aris Tri Haryanto ${ }^{1}$ \\ Sekolah Tinggi Ilmu Ekonomi AUB Surakarta \\ Arisharyanto26@yahoo.co.id \\ Septiana Novita Dewi ${ }^{2}$ \\ Sekolah Tinggi Ilmu Ekonomi AUB Surakarta \\ BRM Suryo Triono ${ }^{3}$ \\ Sekolah Tinggi Ilmu Ekonomi AUB Surakarta
}

\begin{abstract}
ABSTRAK
Orientasi pasar merupakan budaya organisasi yang paling efektif dan efisien dalam menciptakan perilaku yang diperlukan untuk penciptaan nilai unggul bagi pelanggan sehingga dapat menghasilkan kinerja bisnis yang unggul secara berkesinambungan. Intensitas kompetisi atau intensitas persaingan di pasar dapat mendorong perusahaan untuk mengupayakan inovasi yang tinggi guna meraih keunggulan yang kompetitif yang berkelanjutan atas pesaingnya. Melalui intensitas persaingan, perusahaan akan dapat menghasilkan kinerja pemasaran yang optimal. Intensitas persaingan dapat dipengaruhi kondisi orientasi pasar. Intensitas persaingan dapat meningkatkan kinerja pemasaran maupun keunggulan bersaing. Populasi dalam penelitian ini yang menjadi populasi adalah seluruh pimpinan perusahaan finance atau yang mewakili di Wonogiri yang berjumlah 50 orang. Jumlah sampel penelitian ini sejumlah 50 yang berarti seluruh anggota populasi dijadikan sebagai sampel, sehingga penelitiannya merupakan penelitian populasi. Orientasi pasar berpengaruh positif dan signifikan terhadap intensitas persaingan. Orientasi pasar berpengaruh positif dan signifikan terhadap kinerja pemasaran intensitas persaingan berpengaruh positif dan signifikan terhadap kinerja pemasaran. Orientasi pasar berpengaruh positif dan signifikan terhadap keunggulan bersaing. Intensitas persaingan berpengaruh positif dan tidak signifikan terhadap keunggulan bersaing.
\end{abstract}

Kata Kunci : Orientasi Pasar, Intensitas Persaingan, Kinerja Pemasaran, Keunggulan Bersaing

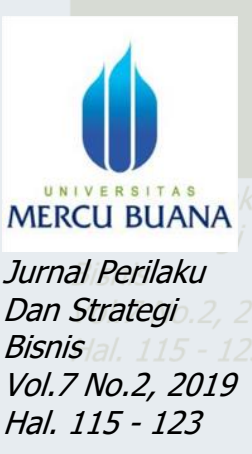

Hal. $115-123$

\begin{abstract}
Market orientation is the most effective and efficient organizational culture in creating the behaviors needed to create superior value for customers so that it can produce superior business performance on an ongoing basis. The intensity of competition or the intensity of competition in the market can encourage companies to strive for high innovation to achieve a sustainable competitive advantage over their competitors. Through the intensity of competition, companies will be able to produce optimal marketing performance. The
\end{abstract}


intensity of competition can be influenced by conditions of market orientation. Competition intensity can improve marketing performance and competitive advantage. The population in this study which became the population were all the heads of finance companies or those representing in Wonogiri, which numbered 50 people. The number of samples of this study is 50 which means that all members of the population are used as samples, so the research is population research. Market orientation has a positive and significant effect on the intensity of competition. Market orientation has a positive and significant effect on marketing performance, competition intensity has a positive and significant effect on marketing performance. Market orientation has a positive and significant effect on competitive advantage. The intensity of competition has a positive and not significant effect on competitive advantage.

\section{Keywords : Market Orientation, Competition Intensity, Marketing Performance, Competitive Advantage}

\section{PENDAHULUAN}

Kinerja pemasaran sangat diperlukan guna keberlanjutan istitusi ataupun perusahaan. Kinerja pemasaran dapat dipengaruhi oleh orientasi pasar. Orientasi pasar adalah budaya organisasi yang paling efektif dan efisien dalam menciptakan perilaku yang diperlukan untuk penciptaan nilai unggul bagi pelanggan sehingga dapat menghasilkan kinerja bisnis yang unggul secara berkesinambungan. Guna menembus pasar baru dan perluasan jaringan pemasaran, diperlukan orientasi pasar. Orientasi pasar merupakan salah satu dari budaya bisnis dalam perluasan jaringan pemasaran maupun pembukaan pasar baru. Orientasi pasar memiliki tiga komponen yaitu orientasi pelanggan, orientasi pesaing, dan koordinasi interfungsional (Idar et al., 2012).

Kinerja pemasaran merupakan indikator bagi organisasi untuk berkembang dan bertahan hidup dalam lingkungan yang dinamis dan bergejolak. Perusahaan yang tidak memiliki kinerja yang baik, akan tertinggal oleh pesaingnya karena pelanggan perusahaan tersebut lambat laun akan meninggalkan dan beralih ke perusahaan pesaing. Penelitian Titahena et al. (2012); Manek (2013);Wachjuni (2014); Pertiwi dan Siswoyo (2017) menyimpulkan bahwa orientasi pasar berpengaruh positif terhadap kinerja pemasaran. Penelitian Hasim et al (2011) mengemukakan bahwa orientasi pasar berpengaruh secara negatif terhadap kinerja bisnis.

Perusahaan dalam upaya memenangkan persaingan, selain kinerja pemasaran maka harus memiliki keunggulan bersaing yang berkelanjutan. Menurut Zimmerer dan Scarborough (Manex, 2013) untuk memenangkan persaingan, sekedar membangun keunggulan bersaing tidaklah mencukupi. Kunci keberhasilannya adalah membangun keunggulan bersaing yang berkesinambungan. Untuk mengurangi tekanan persaingan diperlukan adanya orientasi pasar sehingga perusahaan lebih siap menghadapi persaingan. Kirca et a/(2011) melalui penelitian berjudul Implementation of market orientation in the subsidiaries of global companies: the role of institutional factorsyang menggunakan 79 bagian dari 45 negara menemukan orientasi pasar memiliki hubungan positif dengan institusi resmi harus berkompetisi di pasar di negara tersebut.

Pentingnya peran pelanggan bagi perusahaan, sehingga para pengusaha selalu berlomba-lomba menggali potensi yang terbaik untuk dipersembahkan kepada pelanggan melalui orientasi pasar. Orientasi pasar yang bertumpu pada pelanggan harus selalu ditingkatkan guna memperbaiki kinerja perusahaan bersangkutan. Pentingnya orientasi pasar maka setiap perusahaan berlomba lomba untuk mengetahuinya untuk keberlanjutan bisnis yang dimiliki dalam suatu area ataupun negara.

Charles et al (2012) menyatakan Market orientation has been regarded as a source of competitive advantage and can be an important determinant of firm performance (Orientasi pasar merupakan cara mengetahui sumber persaingan dan merupakan bagian penting 
terhadap kinerja perusahaan). Sarjita (2017) menyimpulkan bahwa variabel orientasi pasar memiliki pengaruh yang positif dan signifikan terhadap kinerja pemasaran pada Sentra Industri Pembuatan Bakpia di Kabupaten Bantul. Orientasi pasar yang baik, maka akan berpengaruh terhadap peningkatan kinerja pemasaran, sebaliknya jika orientasi pasar kurang baik, maka kinerja pemasaran menurun.

Nuvriasari (2012) mendefinisikan orientasi pasar adalah budaya organisasi yang paling efektif dan efisien dalam menciptakan perilaku yang diperlukan untuk penciptaan nilai unggul bagi pelanggan sehingga dapat menghasilkan kinerja bisnis yang unggul secara berkesinambungan.Sudirja (2012) menemukan ada inkonsistensi konsep keunggulan bersaing. Instrumen teori yang digunakan terutama memusat pada Resourced Based View Theory. Intensitas kompetisi atau intensitas persaingan di pasar dapat mendorong perusahaan untuk mengupayakan inovasi yang tinggi guna meraih keunggulan yang kompetitif yang berkelanjutan atas pesaingnya. Melalui intensitas persaingan, perusahaan akan dapat menghasilkan kinerja pemasaran yang optimal, sehingga dengan inovasi dapat memperluas basis pasar lokal dan ditingkatkan untuk preferensi lokal tertentu (Sherlin, 2016).

Persaingan merupakan kenyataan hidup dalam dunia bisnis, sifat, bentuk, dan intensitas persaingan yang terjadi dan cara yang ditempuh oleh para pengambil keputusan stratejik untuk menghadapi para tingkat yang dominan mempengaruhi tingkat keuntungan suatu perusahaan (Siagian, 2013).Intensitas persaingan dapat dipengaruhi kondisi orientasi pasar. Intensitas persaingan dapat meningkatkan kinerja pemasaran maupun keunggulan bersaing. Berdasar uraian di atas, maka penulis tertarik melakukan penelitiian yang berjudul : "Peran Orientasi Pasar, Intensitas Persaingan, Kinerja Pemasaran Dan Keunggulan Bersaing (Studi Perusahaan Finance di Wonogiri)".

\section{KAJIAN LITERATUR \\ Kinerja Pemasaran}

Winata (2010) menjelaskan kinerja pemasaran merupakan elemen penting dari kinerja perusahaan, hal ini dikarenakan kinerja perusahaan merupakan suatu perusahaan yang dapat dilihat dari kinerja pemasaran yang telah dilakukan selama periode tertentu. Selain itu, kinerja pemasaran merupakan konsep untuk mengukur prestasi pemasaran suatu perusahaan. Sitohang, (2010) menjelaskan kinerja pemasaran merupakan hasil atau taraf kesuksesan yang dicapai seseorang dalam menjalankan pekerjaan sesuai dengan wewenang dan tanggung jawabnya.

\section{Keunggulan Bersaing}

Keunggulan bersaing menurut Bharadwaj et al (Sugiarti, 2015) adalah hasil dari implementasi strategi yang memanfaatkan berbagai sumberdaya yang dimiliki perusahaan. Keahlian dan asset yang unik dipandang sebagai sumber dari keunggulan bersaing. Keunggulan bersaing menurut Porter (Sugiarti, 2015) adalah kemampuan suatu perusahaan untuk meraih keuntungan ekonomis di atas laba yang mampu diraih oleh pesaing di pasar dalam industri yang sama.

\section{Intensitas Persaingan}

Intensitas persaingan pasar didefinisikan sebagai faktor-faktor yang mempengaruhi tingkat persaingan yang diukur dari jumlah pesaing utama yang beroperasi dalam pasar, frekuensi tingkat perubahan teknologi dalam industri frekuensi pengenalan produk baru,tingkat manipulasi harga, kesepakatan borongan antara pelanggan dan pesaing, perubahan regulasi dan kebijakan pemerintah, intensitas. 


\section{Orientasi Pasar}

Setiawan (2012) mendefinisikan orientasi pasar sebagai budaya organisasi paling efektif dalam menciptakan perilaku penting untuk penciptaan niali unggul bagi pembeli serta kinerja dalam bisnis. Orientasi pasar adalah sangat bernilai, langka, tidak dapat dipertukarkan, dan tidak dapat ditiru dengan sempurna, yang dinilai sebagai salah satu dari kemampuan internal dan sumber daya yang berpotensi dapat menciptakan keunggulan bersaing (Zhou et al.,2008).

\section{METODE PENELITIAN}

\section{Populasi dan Sampel Penelitian}

Populasi dalam penelitian ini yang menjadi populasi adalah seluruh pimpinan perusahaan finance atau yang mewakili di Wonogiri yang berjumlah 50 orang. Jumlah sampel penelitian ini sejumlah 50 yang berarti seluruh anggota populasi dijadikan sebagai sampel, sehingga penelitiannya merupakan penelitian populasi.

\section{HASIL DAN PEMBAHASAN}

\section{Hasil Analisis Jalur Persamaan 1}

Hasil Persamaan Pertama :

$Y_{1}=0,785 X_{1}+\epsilon_{1}$

$\beta_{1}=$ koefisien regresi orientasi pasar $\left(X_{1}\right)$ sebesar 0,785 , hal ini menunjukkan bahwa orientasi pasar $\left(X_{1}\right)$ berpengaruh positif terhadap intensitas persaingan $\left(X_{2}\right)$. Hal ini berarti apabila orientasi pasar $\left(X_{1}\right)$ lebih baik, maka Intensitas Persaingan $\left(X_{2}\right)$ akan meningkat secara signifikan.

\section{Hasil Analisis Jalur Persamaan 2}

$Y_{2}=0,289 X_{1}+0,568 X_{2}+\epsilon_{2}$

$\beta_{4}=$ koefisien regresi orientasi pasar $\left(X_{1}\right)$ sebesar 0,289 , hal ini menunjukkan bahwa orientasi pasar $\left(X_{1}\right)$ berpengaruh positif terhadap kinerja pemasaran $\left(Y_{1}\right)$. Hal ini berarti apabila orientasi pasar $\left(X_{1}\right)$ lebih baik, maka kinerja pemasaran $\left(Y_{1}\right)$ akan meningkat secara signifikan.

$\beta_{5}=$ koefisien regresi intensitas persaingan $\left(X_{2}\right)$ sebesar 0,568 , hal ini menunjukkan bahwa intensitas persaingan $\left(X_{2}\right)$ berpengaruh positif terhadap kinerja pemasaran $\left(Y_{1}\right)$. Hal ini berarti bahwa apabila intensitas persaingan $\left(\mathrm{X}_{2}\right)$ ditingkatkan, maka kinerja pemasaran $\left(\mathrm{Y}_{1}\right)$ akan meningkat secara signifikan.

\section{Hasil Analisis Jalur Persamaan 3}

$Y_{2}=0,874 X_{1}+0,012 X_{2}+\epsilon_{2}$

$\beta_{4}=$ koefisien regresi orientasi pasar $\left(X_{1}\right)$ sebesar 0,874 , hal ini menunjukkan bahwa orientasi pasar $\left(X_{1}\right)$ berpengaruh positif terhadap keunggulan bersaing $\left(Y_{2}\right)$. Hal ini berarti apabila Orientasi pasar $\left(X_{1}\right)$ lebih baik, maka keunggulan bersaing $\left(Y_{2}\right)$ akan meningkat secara signifikan.

$\beta_{5}=$ koefisien regresi intensitas persaingan $\left(X_{2}\right)$ sebesar 0,012 , hal ini menunjukkan bahwa intensitas persaingan $\left(X_{2}\right)$ berpengaruh positif terhadap keunggulan bersaing $\left(Y_{2}\right)$. Hal ini berarti bahwa apabila intensitas persaingan $\left(\mathrm{X}_{2}\right)$ ditingkatkan, maka keunggulan bersaing $\left(Y_{2}\right)$ akan meningkat secara signifikan. 


\section{UJI T}

\section{Uji t persamaan 1}

Tabel 1. Hasil uji t Persamaan 1

Coefficients $\mathrm{s}^{\mathrm{a}}$

\begin{tabular}{|rl|r|r|r|r|r|}
\hline \multirow{2}{*}{ Model } & \multicolumn{2}{|c|}{$\begin{array}{c}\text { Unstandardized } \\
\text { Coefficients }\end{array}$} & \multicolumn{2}{c|}{$\begin{array}{c}\text { Standardized } \\
\text { Coefficients }\end{array}$} & & \\
\cline { 3 - 5 } & & \multicolumn{1}{|c|}{$\mathrm{B}$} & Std. Error & \multicolumn{1}{|c|}{ Beta } & \multicolumn{1}{c|}{$\mathrm{t}$} & \multicolumn{1}{c|}{ Sig. } \\
\hline 1 & (Constant) & 10,540 & 2,226 & & 4,734 &, 000 \\
& Orientasi Pasar &, 662 &, 075 &, 785 & 8,766 &, 000 \\
\hline
\end{tabular}

a. Dependent Variable: Intensitas Persaingan

Sumber : Data yang diolah, 2019

Orientasi pasar $\left(\mathrm{X}_{1}\right)$ berpengaruh signifikan terhadap Intensitas Persaingan $\left(\mathrm{X}_{2}\right)$ pimpinan perusahaan finance atau yang mewakili di Wonogiri, hal ini dapat dilihat dari nilai signifikansi yaitu $0,000<0,05$. Hipotesis pertama yang menyatakan orientasi pasar $\left(X_{1}\right)$ berpengaruh signifikan terhadap intensitas persaingan $\left(X_{2}\right)$ pimpinan perusahaan finance atau yang mewakili di Wonogiri terbukti.

\section{Uji t persamaan 2}

Tabel 2. Hasil uji t Persamaan 2

Coefficients $^{\mathrm{a}}$

\begin{tabular}{|c|c|c|c|c|c|c|}
\hline \multirow[b]{2}{*}{ Mod } & & \multicolumn{2}{|c|}{$\begin{array}{c}\text { Unstandardized } \\
\text { Coefficients }\end{array}$} & \multirow{2}{*}{$\begin{array}{c}\begin{array}{c}\text { Standardized } \\
\text { Coefficients }\end{array} \\
\text { Beta }\end{array}$} & \multirow[b]{2}{*}{$\mathrm{t}$} & \multirow[b]{2}{*}{ Sig. } \\
\hline & & $B$ & Std. Error & & & \\
\hline \multirow[t]{3}{*}{1} & (Constant) & 4,758 & 1,305 & & 3,648 &, 001 \\
\hline & Orientasi Pasar & 125 & .059 & 289 & 2,120 & 039 \\
\hline & Intensitas Persaingan & ,291 & , 070 & ,568 & 4,161 &, 000 \\
\hline
\end{tabular}

a. Dependent Variable: Kinerja Pemasaran

Sumber : Data yang diolah, 2019

Orientasi pasar $\left(X_{1}\right)$ berpengaruh signifikan terhadap kinerja pemasaran $\left(Y_{1}\right)$ pimpinan perusahaan finance atau yang mewakili di Wonogiri, hal ini dapat dilihat dari nilai signifikansi yaitu $0,039<0,05$. Hipotesis kedua yang menyatakan Orientasi pasar $\left(X_{1}\right)$ berpengaruh signifikan terhadap kinerja pemasaran $\left(\mathrm{Y}_{1}\right)$ pimpinan perusahaan finance atau yang mewakili di Wonogiri terbukti.

Intensitas Persaingan $\left(X_{2}\right)$ berpengaruh signifikan terhadap kinerja pemasaran $\left(Y_{1}\right)$ pimpinan perusahaan finance atau yang mewakili di Wonogiri, hal ini dapat dilihat dari nilai signifikansi yaitu $0,000<0,05$. Hipotesis ketiga yang menyatakan Intensitas Persaingan $\left(X_{2}\right)$ berpengaruh signifikan terhadap kinerja pemasaran $\left(Y_{1}\right)$ pimpinan perusahaan finance atau yang mewakili di Wonogiri terbukti.

\section{Uji t persamaan 3}

Tabel 3. Hasil uji t Persamaan 3

Coefficients $^{\mathrm{a}}$

\begin{tabular}{|c|c|c|c|c|c|c|}
\hline \multirow[b]{2}{*}{ Model } & & \multicolumn{2}{|c|}{$\begin{array}{l}\text { Unstandardized } \\
\text { Coefficients }\end{array}$} & \multirow{2}{*}{$\begin{array}{c}\begin{array}{c}\text { Standardized } \\
\text { Coefficients }\end{array} \\
\text { Beta }\end{array}$} & \multirow[b]{2}{*}{$\mathrm{t}$} & \multirow[b]{2}{*}{ Sig. } \\
\hline & & $\mathrm{B}$ & Std. Error & & & \\
\hline 1 & (Constant) & 6,924 & 1,366 & & 5,070 &, 000 \\
\hline & Orientasi Pasar & ,490 & ,062 & ,874 & 7,944 & ,000 \\
\hline & Intensitas Persaingan &, 008 &, 073 &, 012 &, 112 & ,912 \\
\hline
\end{tabular}

a. Dependent Variable: Keunggulan Bersaing

Sumber : Data yang diolah, 2018 
Orientasi pasar $\left(X_{1}\right)$ berpengaruh signifikan terhadap keunggulan bersaing $\left(Y_{2}\right)$ pimpinan perusahaan finance atau yang mewakili di Wonogiri, hal ini dapat dilihat dari nilai signifikansi yaitu $0,000<0,05$. Hipotesis keempat yang menyatakan Orientasi pasar $\left(X_{1}\right)$ berpengaruh signifikan terhadap keunggulan bersaing $\left(\mathrm{Y}_{2}\right)$ pimpinan perusahaan finance atau yang mewakili di Wonogiri terbukti.

Intensitas Persaingan $\left(\mathrm{X}_{2}\right)$ berpengaruh signifikan terhadap keunggulan bersaing $\left(\mathrm{Y}_{2}\right)$ pimpinan perusahaan finance atau yang mewakili di Wonogiri, hal ini dapat dilihat dari nilai signifikansi yaitu 0,912<0,05. Hipotesis kelima yang menyatakan Intensitas Persaingan $\left(\mathrm{X}_{2}\right)$ berpengaruh signifikan terhadap keunggulan bersaing $\left(\mathrm{Y}_{2}\right)$ pimpinan perusahaan finance atau yang mewakili di Wonogiri tidak terbukti.

\section{Koefisien Determinasi $\left(\mathbf{R}^{2}\right)$ Total atau Varian Total}

Koefisien Determinasi $\left(R^{2}\right)$ Total diperoleh sebagai berikut:

Uji $\mathrm{R}^{2}$ persamaan 1 didapatkan hasil sebesar 0,616

$e_{1}=\sqrt{1-R_{1}^{2}}=\sqrt{1-0,616}=\sqrt{0,384}=0,6197$

Uji $R^{2}$ Persamaan 2 didapatkan hasil sebesar 0,664

$\mathrm{e}_{2}=\sqrt{1-\mathrm{R}_{2}{ }^{2}}=\sqrt{1-0,664}=\sqrt{0,336}=0,5797$

Uji $R^{2}$ Persamaan 3 didapatkan hasil sebesar 0,781

$\mathrm{e}_{2}=\sqrt{1-\mathrm{R}_{2}{ }^{2}}=\sqrt{1-0,781}=\sqrt{0,219}=0,4680$

$\mathrm{R}^{2}$ total $=1-\left(\mathrm{e}_{1}^{2} \times \mathrm{e}_{2}^{2} \times \mathrm{e}_{3}^{2}\right)$

$=1-(0,384 \times 0,336 \times 0,219)=1-0,0283=0,9717$

Nilai $R^{2}$ total sebesar 0,9717 artinya variabel kinerja pemasaran $\left(Y_{1}\right)$ dan keunggulan bersaing $\left(\mathrm{Y}_{2}\right)$ pimpinan perusahaan kayu jati atau yang mewakili di Kabupaten dapat dijelaskan variabel Orientasi pasar $\left(X_{1}\right)$ dan Intensitas Persaingan $\left(X_{2}\right)$ sebesar $97,17 \%$ dan sisanya sebesar $2,83 \%$ dijelaskan oleh variabel lain diluar model misalnya modal pemasaran.

Pengaruh Langsung, Tidak Langsung, dan Total Pengaruh

Tabel 4. Pengaruh Langsung, Tidak Langsung dan Total Pengaruh

\begin{tabular}{|c|c|c|c|}
\hline \multirow[t]{2}{*}{ Keterangan } & \multicolumn{2}{|r|}{ Pengaruh } & \multirow[t]{3}{*}{ Total pengaruh } \\
\hline & & $\begin{array}{c}\text { Tidak } \\
\text { Langsung }\end{array}$ & \\
\hline $\mathrm{OP} \rightarrow \mathrm{KP}$ & $P_{3}=0,289$ & & \\
\hline $\mathrm{OP} \rightarrow \mathrm{KP}$ & $P_{4}=0,874$ & & \\
\hline $\mathrm{OP} \rightarrow \mathrm{IP} \rightarrow \mathrm{KP}$ & & $\begin{array}{l}P_{1} \times P_{7}= \\
0,785 \times 0,568=0,446\end{array}$ & $\begin{array}{l}P_{4}+\left(P_{1} \times P_{7)}=\right. \\
0,289+0,446=0,735\end{array}$ \\
\hline $\mathrm{OP} \rightarrow \mathrm{IP} \rightarrow \mathrm{KB}$ & & $\begin{array}{l}P_{2} \times P_{7}= \\
0,785 \times 0,012=0,009\end{array}$ & $\begin{array}{l}P_{5}+\left(P_{2} \times P_{7}\right)= \\
0,874+0,009=0,883\end{array}$ \\
\hline
\end{tabular}

Sumber: Data yang diolah, 2019

Pengaruh Total ( Total Effect)

Pengaruh total (total effect) variabel Orientasi pasar $\left(X_{1}\right)$ terhadap kinerja pemasaran $\left(Y_{1}\right)$ pimpinan perusahaan finance atau yang mewakili di Wonogiri melalui Intensitas Persaingan $\left(\mathrm{X}_{2}\right)$ adalah 0,735 . 
Pengaruh total (total effect) variabel orientasi pasar terhadap keunggulan bersaing pimpinan perusahaan finance atau yang mewakili di Wonogiri melalui Intensitas Persaingan adalah 0,883

Hasil analisis jalur secara lengkap dalam penelitian ini dapat dijelaskan secara rinci pengaruh antar variabel penelitian pada gambar berikut ini.

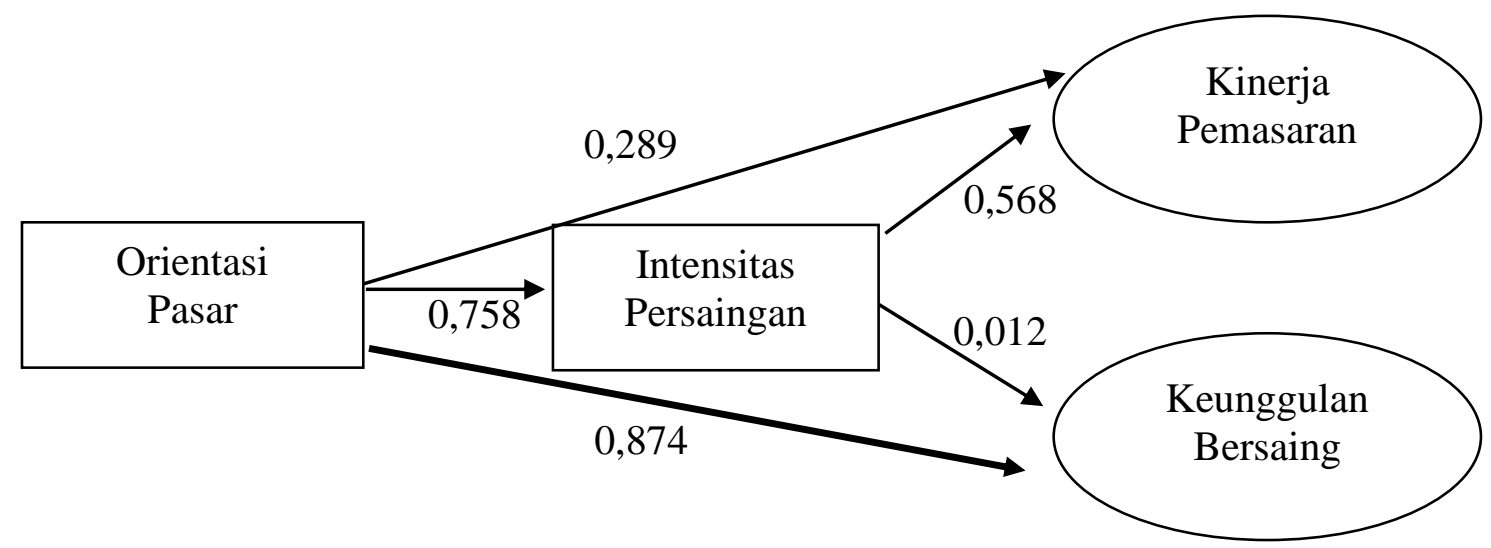

Gambar 1. Pengaruh langsung, Tidak Langsung, dan Total Pengaruh

\section{KESIMPULAN}

Berdasarkan urain pada bab terdahulu, khususnya dalam analisis dan pembahasan dapat ditarik kesimpulan sebagai berikut :

1. Hasil dari penelitian ini menunjukkan bahwa :

a. Variabel Orientasi Pasar berpengaruh positif dan signifikan terhadap Intensitas Persaingan.

b. Orientasi Pasar berpengaruh positif dan signifikan terhadap Kinerja Pemasaran

c. Intensitas Persaingan berpengaruh positif dan signifikan terhadap Kinerja Pemasaran

d. Orientasi Pasar berpengaruh positif dan Signifikan terhadap Keunggulan Bersaing.

e. Intensitas Persaingan berpengaruh positif dan tidak Signifikan terhadap Keunggulan Bersaing.

2. Hasil uji secara serempak (Uji $F$ ) pada persamaan kedua diketahui besarnya nilai $F=$ 83,890 signifikansi 0,000<0,05, sehingga dapat disimpulkan secara bersama-sama Orientasi pasar $\left(X_{1}\right)$ dan Intensitas Persaingan $\left(X_{2}\right)$ mempengaruhi keunggulan bersaing $\left(\mathrm{Y}_{2}\right)$ pimpinan perusahaan kayu jati atau yang mewakili di Kabupaten Karanganyar.

3. Nilai $R^{2}$ total sebesar 0,9717 artinya variabel kinerja pemasaran $\left(Y_{1}\right)$ dan keunggulan bersaing $\left(Y_{2}\right)$ pimpinan perusahaan kayu jati atau yang mewakili di Kabupaten dapat dijelaskan variabel Orientasi pasar $\left(X_{1}\right)$ dan Intensitas Persaingan $\left(X_{2}\right)$ sebesar $97,17 \%$ dan sisanya sebesar $2,83 \%$ dijelaskan oleh variabel lain diluar model misalnya modal pemasaran.

4. Hasil analisis jalur menunjukkan bahwa:

a. Peningkatan Orientasi pasar lebih efektif melalui jalur tidak langsung, Intensitas persaingan terhadap kinerja pemasaran karena hasil pengaruh tidak langsung lebih besar dibandingkan pengaruh langsung.

b. Peningkatan Keunggulan bersaing lebih efektif melalui jalur langsung, karena hasil pengaruh langsung lebih besar dibandingkan pengaruh tidak langsung

\section{SARAN}

Dalam meningkatkan kinerja manajerial di perusahaan finance Wonogiri lebih mengutamakan variabel orientasi pasar secara lagsung karena memiliki nilai pengaruh yang 
lebih dominan guna menghasilkan kinerja manajerial yang lebih baik lagi. Hal ini yang dapat dilakukan untuk meningkatkan orientasi pasar melalui dengan cara:

1. Perusahaan ini perlu memahami apa yang dirasakan pelanggan guna keberlangsungan usahanya demi meningkatnya keunggulang dalam persaingan.

2. Meningkatkan orientasi pasar demi keunggulan bersaing maka perusahaan harus memahami keinginan orang yang menjadi pelanggan guna keberlangsungan usaha

3. Sikap dan tindakan dari perusahaan sangat mendukung inovasi produk.

\section{DAFTAR PUSTAKA}

Afsharghasemi, A., M. Zain, M. Sambasvian, dan S. N. S. Imm. 2013. Market Orientation, Government Regulation, Competitive Advantage and Internationalization of SMEs: A Study In Malaysia. Journal of Business Administration Research 2(2): 13-22.

Ahmad Ali Syahbana. (2008). Pengaruh Intensitas Persaingan, Lokasi, Kualitas Pramuniaga, Dan Kesadaran Akan Harga Terhadap Strategi Bisnis Berbasis Pelayanan Dalam Meningkatkan Kinerja Outlet (Studi Pada Outlet-Outlet Pt. Telkomsel Wilayah Kota Semarang). Tesis. UNDIP.

Ahmad Yahya Surya. 2010. Winata Mengukur Kinerja Pemasaran: Kajian Konseptual Perkembangan Teori. Jurnal Riset Akuntansi Dan Bisnis Vol 10 No .2 /September 2010. HAL. 194-219.

Baker, W. E. dan J. M. Sinkula. 2009. The Complementary Effects of Market Orientation and Entrepreneurial Orientation on Profitability in Small Business. Journal of Small Business Management 47(4): 443-464.

Datri Mulyani. (2015). Upaya Meningkatkan Kinerja Pemasaran Melalui Orientasi Pasar Dan Orientasi Kewirausahaan Dengan Inovasi Sebagai Variabel Intervening (Studi Empiris Pada Usaha Mikro Kecil Dan Menengah Kota Semarang). Skripsi. UNDIP

David Hunger dan Thomas Wheleen, Manajemen Strategis. 2013. Yogyakarta: Penerbit ANDI

Faisal dan Prabowo (2006) Pengaruh Intensitas Persaingan Pasar, Strategi Dan Ketidakpastian Lingkungan Yang Dirasakan Terhadap Penggunaan Informasi Sistem Akuntansi Manajemen Dan Kinerja Unit Bisnis. JAAI Volume 10 No. 1, Juni 2006: 45 63

Ferdinand, A. 2002. Structural Equation Modeling Dalam Penelitian Manajemen. Edisi

Gable, M., and M. Topol. 2000. Planing Practices of Small Scale Retilers. American

I Nengah Aryana, I Made Wardana, Ni Nyoman Kerti Yasa. (2017). Membangun Keunggulan Bersaing Melalui Kinerja Sistem Informasi Dan Customer Intimacy Dalam Meningkatkan Kinerja Pemasaran (Studi Pada Industri Perhotelan Di Bali). E-Jurnal Ekonomi dan Bisnis Universitas Udayana 6.4 (2017) ISSN : 2337-3067. Hal. 1343-1364

Idar, R., Y. Yusoff, dan R. Mahmood. 2012. The Effect of Market Orientation As Mediator to Strategic Planning Practices and Performance Relationship: Evidence From Malaysian SMEs. Procedia Economic and Finance 4(2012): 68-78.

Imam Gozali dan CH Asta Nugraha. (2015). Analisis Kinerja Pemasaran Untuk Mencapai Keunggulan Bersaing (Studi Pada Centra Industri Pakaian Batik Di Pekalongan). 
Prosiding Seminar Nasional \& Call For Papers 2015 Fakultas Ekonomika Dan Bisnis. ISBN : 978-602-14119-1-9. Hal. 108-122.

Liu, Y., Y. Lie, dan J. Xue. 2011. Ownership, Strategic Orientation and Internationalization in Emerging Markets. Journal of World Business 46: 381-393.

Nuvriasari, Wicaksono dan Sumiyarsih. 2012. Peran Orientasi Pasar, Orientasi Kewirausahaan Dan Strategi Bersaing Terhadap Peningkatan Kinerja UKM. Ekuitas: Jurnal Ekonomi dan Keuangan ISSN 1411-0393. Akreditasi No. 80/DIKTI/Kep/2012. Volume 19, Nomor 2, Juni 2015 : $241-259$

Nuvriasari, A. 2012. Peran Dukungan Organisasional, Kompetensi Teknologi dan Lingkungan Eksternal Dalam Rangka Mendorong Pengadopsian E-Commerce Pada Usaha Kecil dan Menengah. Jurnal Siasat Bisnis 16(2): 205-217.

Nuvriasari, A. dan U. Hadiyati. 2008. Governance di Lingkungan Usaha Kecil Menengah Studi Empiris pada Usaha Kecil Menengah di Propinsi DIY. SINERGI: Kajian Bisnis dan Manajemen 10(2): 121-140.

Olivares, A. M. dan W. Lado. 2008. Market Orientation and Business Economic Performance A Mediated Model. International Journal of Service Industry Management 14(3): 284309

Pardi, Suharyono, Suyadi Imam, Arifin Zainul. 2014. The Effect of Market Orientation and Entrepreneurial Orientation toward Learning Orientation, Innovation, Competitive Advantages and Marketing Performance. European Journal of Business and Management. 6 (21): 69-80.

Porter, 1993. Competitive Strategiy, Terjemahan. Agus Maulana, Erlangga, Jakarta, 1993, hIm. 32. 26 Basu Swastha, Sukotja, Op.Cit, hlm.211-212

Sitohang, Sonang. 2005. Faktor-Faktor Yang Mempengaruhi Keberhasilan Sentra Industri Kecil. JAMBSP. Jurnal Akuntansi, Manajemen Bisnis dan Sektor Publik, 1(3): 291-310.

Sondang P. Siagian, Manajemen Stratejik, ( Jakarta: PT.Bumi Aksara,2013)

Sukarno, Gendut. 2009. Corporate Reputation Melalui Corporate Social Responsibility di Lingkungan PT.Perkebunan Nusantara. X. Jurnal Riset Ekonomi dan Manajemen.

Taleghani, M., S. Gilaninia, dan S.M. Talab. 2013. Relationship between Market Orientation Culture and Business Performance. Interdisciplinary Journal of Contemporary Research in Business 5(1): 949-954.

Zhou, K. Z., J. R. Brown, dan C. S. Dev. 2008. Market Orientation, Competitive Advantage, And Performance: A Demand-Based Perspective. Journal Of Business Research 62(2008): 1062-1070.

Kasmir. 2012. Kewirausahaan. Jakarta :PT Raja Grafindo Persada. 